\title{
AOR
}

Selected Papers of \#AolR2020:

The 22nd Annual Conference of the

Association of Internet Researchers

Virtual Event / 13-16 Oct 2021

\section{PERFORMATIVE MEDIA POLICY: SECTION 230'S EVOLUTION FROM FOOTNOTE TO LOYALTY OATH}

\author{
Aram Sinnreich \\ American University \\ Mariana Sanchez Santos \\ American University \\ Patricia Aufderheide \\ American University
}

This study examines the legislative evolution of Section 230 of the Communications Act of 1934, a widely discussed and frequently misunderstood dimension of American telecommunications policy that provides a "safe harbor" provisionally shielding internet companies from liability for law-breaking content published by third parties who use their platforms and networks. Though this provision originated in the mid-1990s as an effort to minimize the legal and economic risks facing fledgling internet startups, we argue that efforts to reform it during the Trump era reflected an unprecedented transformation of an arcane policy point into a highly public subject for "messaging bills" intended principally to signal political loyalty to the president.

\section{What is Section 230?}

Sec. 230 (also known as Sec. 509 of the Telecommunications Act of 1996) is a deceptively simple clause of American communications law - twenty-six words that have had a profound impact on the development of the internet as a technological infrastructure, an industry, and a social and cultural architecture, and is frequently referred to as "the most important law in tech." At the time of its passage, it was seen as something of a "Frankenstein" provision welded awkwardly onto existing comm policy to make it internet-ready, combining the pet concern of a few legislators (as well as VicePresident Gore's wife, Tipper) about protecting children from online "indecency" with the equally arcane concern of a few other legislators to proactively support "internet freedom" by clearing obstacles to investment in the burgeoning speculative bubble surrounding "dot-com" companies in the mid-to-late 1990s (Kosseff, 2019).

In essence, Sec. 230 states that operators of "online computer services" will not be held liable for actions of customers on their platforms. Furthermore, platforms' efforts to 
regulate information flow in line with material they deem "objectionable" will not affect that promise. At the time, social media was scarcely imagined by lawmakers, and protoInternet services included Compuserve, Prodigy, and AOL, along with aspiring telcos. Sec. 230 has since become a weight-bearing pillar of the Internet, enabling startups that offer services as diverse as auctions, restaurant ratings, dropboxes, project management, and dating apps to develop functional business and economic models based on minimizing risk of secondary liability for their users' actions. Yelp, Slack, eBay, and nearly every other leading internet platform depends on Sec. 230 for fiscal viability.

\section{Reforming Section 230}

In the years since the law's passage, some leading online platforms have developed into elaborate and algorithmically-aided architectures of information flow, pioneering a new and unregulated space between mediated and interpersonal communication. Facebook, Google News, Twitter, Parler, Reddit, and many smaller platforms all operate in a space between the traditional regulatory fora of media and telecommunications. This evolution has not only given rise to a powerful new "surveillance capitalism" (Zuboff, 2015) industry, but has undermined traditional journalism business models and practices, accelerated widespread disinformation distribution, and supercharged the capacity of militant terrorist organizations to amplify their messages of hate.

Thus, while benefiting financially from their role at the nexus of the new digital public sphere, social media platforms have also been subject to increasing pressure in threading the needle between their telecommunications and traditional media functions, with calls from both sides of the political aisle to both increase and decrease the role they play in actively mediating the flow of information through their networks (Gillespie, et al, 2020).

Increasingly, these calls have come from "inside the house," with a rising tide of legislators proposing legislation seeking to amend the Telecommunications Act. According to our own analysis of the 140 bills targeting this law over the past two decades, both the volume and the nature of these bills changed drastically in the Trump era. Earlier bills were policy-oriented, focused on issues such as cybersecurity, consumer privacy, and net neutrality. There were only 17 such bills through November, 2018 , and none of them addressed Section 230 specifically.

Beginning in December, 2018, the bills became far more common, and increasingly they aimed to reform or abolish Section 230, either in name or in deed. There were 63 bills to amend the Telecommunications Act between December, 2018 and May, 2020. After Twitter flagged and masked some tweets by Donald Trump calling for violence against civil rights protesters that month, he retaliated by using the elimination of safe harbors as a threat, tweeting "REVOKE 230!" on May 29th. Thereafter, the pace of telecom reform bills accelerated again, with 41 more such bills in the seven and a half months until Trump left office. 


\section{The Messaging is the Message}

We analyzed the content of these telecom policy reform bills, and found that, increasingly between 2018-2021, the bills became less focused on specific "wonky" policy issues, and more uniform in their calls to repeal or amend Section 230 for the purposes of fighting "censorship" or providing "accountability" for "bad actors" who "abuse" the provision - all talking points that reflect the grievances of Trump and his allies in spreading hate speech and disinformation via social media.

We believe that these bills, which flourished following the 2018 U.S. midterm elections, represent a novel and unique evolution of an older legislative strategy - typically referred to as "messaging bills" - which are intended to be performative and communicative, rather than instrumental of policy change. Historically, messaging bills were "aspirational in policy terms" (Lee, 2018, p. 1471), aligning messaging and agenda-setting for the minority party.

However, the "unprecedented nature of the Trump administration (Gelman, 2018, p. 494) altered the function of messaging bills, essentially turning them into a vehicle for legislators to signal their political loyalty to the president. Specifically, Trump's use of social media - and its increasing centrality to political speech - marked a change in the lawmaking process, dislodging the party as the convening institution and creating a top-down agenda setting flow. Thus, legislators who propose amending Section 230, though they may not understand how the law actually works, let alone the broader implications of changing it, are nonetheless cognizant that the social media attention such bills garner help to advertise their loyalty to Trump among core constituents.

Finally, we observe that, empty though the legislative content of these bills may be, the messaging works. According to our analysis of Factiva's database, prevalence of "censorship" and "social media bias" frames spiked in the news coverage of Section 230 during these years.

\section{References}

Gelman, J. (2018). If Congress Is So Dysfunctional, Why Is Its Staff So Busy? A Congressional Fellow's Perspective. PS: Political Science \& Politics, 51(2), 494495. doi:10.1017/S1049096518000288

Gillespie, T., Aufderheide, P., Carmi, E., Gerrard, Y., Gorwa, R., Matamoros-Fernández, A., Roberts, S. T., Sinnreich, A. \& Myers West, S. (2020). Expanding the debate about content moderation: Scholarly research agendas for the coming policy debates. Internet Policy Review, 9(4). DOI: 10.14763/2020.4.1512

Kosseff, J. (2019, Dec. 19). What's in a Name? Quite a Bit, If You're Talking About Section 230. Lawfare. Accessed at https://www.lawfareblog.com/whats-namequite-bit-if-youre-talking-about-section-230 
Lee, F. (2018). The $115^{\text {th }}$ Congress and Questions of Party Unity in a Polarized Era, Journal of Politics, 80 (4). https://dx.doi.org/10.1086/699335

Zuboff, S. (2015). Big other: surveillance capitalism and the prospects of an information civilization. Journal of Information Technology, 30(1), 75-89. 